\title{
Monitoring water quality in estuarine environments: lessons from the MAGEST monitoring program in the Gironde fluvial-estuarine system
}

\author{
H. Etcheber ${ }^{1}$, S. Schmidt ${ }^{1}$, A. Sottolichio ${ }^{2}$, E. Maneux ${ }^{3}$, G. Chabaux ${ }^{2}$, J.-M. Escalier ${ }^{1}$, H. Wennekes ${ }^{1}$, H. Derriennic ${ }^{2}$, \\ M. Schmeltz ${ }^{2}$, L. Quéméner ${ }^{4}$, M. Repecaud ${ }^{4}$, P. Woerther ${ }^{4}$, and P. Castaing ${ }^{2}$ \\ ${ }^{1}$ CNRS, UMR 5805 EPOC, Talence, France \\ ${ }^{2}$ Université Bordeaux 1, UMR 5805 EPOC, Talence, France \\ ${ }^{3}$ GEO Transfert - ADERA, Pessac, France \\ ${ }^{4}$ Ifremer-Brest, Plouzané, France
}

Received: 23 October 2010 - Published in Hydrol. Earth Syst. Sci. Discuss.: 7 December 2010

Revised: 22 February 2011 - Accepted: 3 March 2011 - Published: 10 March 2011

\begin{abstract}
The Gironde Estuary, one of the largest European ones, presents temporary low dissolved oxygen content in its fluvial section close to the Bordeaux urban area. In a context of population growth and of long-term environmental changes, the development of a high-frequency monitoring programme of the fluvial-estuarine system of the Gironde, called MAGEST (MArel Gironde ESTuary), had appeared essential to address current and future water-quality issues/evaluations. The objectives of the MAGEST survey program are to establish a reference database to improve the knowledge of the Gironde Estuary functioning, encompassing the aspects of hydrology, sediment dynamics and biogeochemistry. Through examples of results from intratidal to seasonal time scales, we demonstrate how such a long-term, high-frequency monitoring of a fluvio-estuarine system is of valuable interest to extract the main trends of its functioning and of the water quality in relation to external forcings (climatology, urban wastes, land use, ...) and to predict the future evolution of an estuary with global and environmental changes.
\end{abstract}

\section{Introduction}

With its $625 \mathrm{~km}^{2}$, the Gironde Estuary (S-W France) is one of the largest European estuaries in terms of surface area and mean annual discharges $\left(\sim 1100 \mathrm{~m}^{3} \mathrm{~s}^{-1}\right.$; Etcheber et

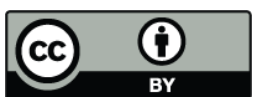

Correspondence to: S. Schmidt (s.schmidt@epoc.u-bordeaux1.fr) al., 2007) (Fig. 1). Due to a strong marine influence, the residence times of water and suspended particulate matter (SPM) are long, leading to a well-developed turbidity maximum zone (TMZ), with SPM concentrations up to few $\mathrm{g} \mathrm{L}^{-1}$ (Allen et al., 1977, 1980; Jouanneau et al., 1999; Saari et al., 2010). The Gironde Estuary was estimated to contribute $60 \%$ of the input of fine sediments to the continental shelf of the Bay of Biscay (Castaing and Allen, 1981). Although this system drains one of the less urbanized/industrialized watersheds in Europe (Abril et al., 2002; Etcheber et al., 2007), it is polluted by heavy metals, preventing oyster and mussel production within the estuary (Latouche, 1988). This chronic metal pollution is due to former mining and smelting activities during the late 19th century in the upper reaches of a tributary (Schäfer et al., 2006; Saari et al., 2007). Persistent organic pollutants have been also measured through the French RNO network survey (Réseau National d'Observation de la qualité du milieu marin, http://www.ifremer.fr/lern/Pages/ Programme/rno.htm). These pollutions are relatively well documented and explained.

Regarding the ecosystem of the Gironde estuary, a critical problem is the occurrence of temporary low dissolved oxygen content in its fluvial section close to the Bordeaux urban area. Such episodic hypoxias are of major concern regarding migratory fishes, like salmon or eel. The first hypoxia event was recorded in 1962. Thereafter several episodes have been reported, in particular during severe droughts $(1976,1989)$. At present, the question is more the timing and the duration of these episodes during the year. In the absence of historical detailed dataset, it is difficult to clearly determine the origin of these hypoxias. Notwithstanding, environmental changes

Published by Copernicus Publications on behalf of the European Geosciences Union. 
have been observed over the last decades. The bathymetry had changed drastically upstream Bordeaux, with a deepening of the Garonne bed due to intensive ballast extraction from 1960 to 1982 . Up to $30 \mathrm{~km}$ upstream Bordeaux, the riverbed, previously gravelly, is now muddy, which promotes an increase of turbidity due to sediments resuspension. Over the last 15 years, the intensification of low-water level periods maintains for several months the maximum turbidity zone in the upper estuary. Increases in temperature $\left(+2^{\circ} \mathrm{C}\right)$ and salinity $(+3)$ of central estuarine waters were also registered between 1978 and 2003 (Savoye et al., 2009), with a direct influence on behavior and distribution of zooplankton communities (David et al., 2005). In future, the combination of TMZ stagnation and temperature increase could drastically lower dissolved oxygen saturation in summers.

Likewise, rivers and estuarine systems around the world are affected by changes in land use, hydrological and biogeochemical cycles mainly driven by the continuous increase in population (Neal, 2004; Schmidt et al., 2007; Perillo et al., 2007; Garel et al., 2009; Borja et al., 2010; Boyer et al., 2010; Sabater and Stevenson, 2010). Land use and climate, in conjunction with geology, are the ultimate determinants of hydrology and water quality, thereby acting as the primary drivers of change in structure and function of rivers (Meybeck and Helmer, 1989; Alcamo et al., 2007; Hoffman et al., 2010; Zolina et al., 2010). Thus, predicting response of estuarine system to global changes and local impacts is critical to protect or restore good water quality and ecosystem functioning (Johnson et al., 2009; Stevenson and Sabater, 2010). The importance of time series in aquatic system has been recognized long ago to better understand the long-term changes (Neal, 2004; Baborowski et al., 2004; Blain et al., 2004; Horowitz, 2009).

In such a context of long-term environmental changes, i.e. climate and population growth, the development of a longterm monitoring program of the fluvial-estuarine system of the Gironde had thus appeared essential for addressing current and future water-quality issues and evaluations. The objectives of the MAGEST network since 2005 was to establish a reference database to improve the knowledge of the Gironde Estuary functioning, encompassing the aspects of hydrology, sediment dynamics and biogeochemistry. After a brief description of the Gironde fluvio-estuarine system, we present the automated stations and examples of dataset to illustrate the interest of this monitoring. Such high-frequency time-series would permit to better understand the functioning of the Gironde Estuary and the evolution of its water quality in relation with external forcings (climatology, urban discharges, land use, ...) and to predict the potential evolutions of this system with environmental changes. We conclude on the interest of long-term, high frequency monitoring of water quality in transient waters, based on the use of real-time continuous systems, not common in estuarine systems.

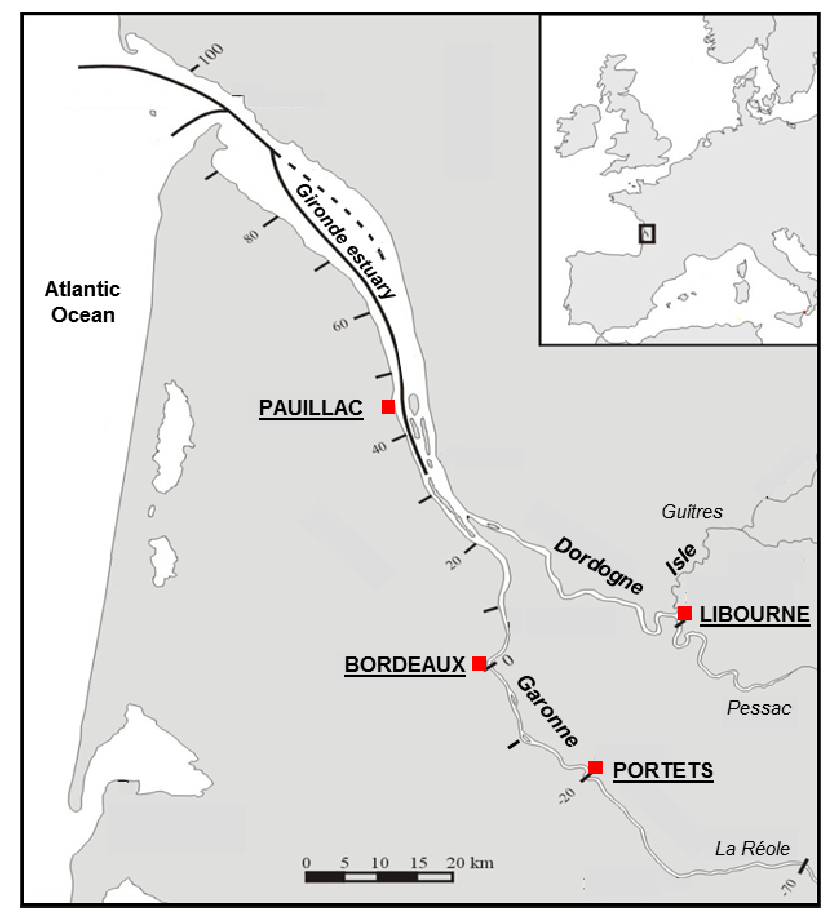

Fig. 1. Location map of the Gironde fluvial-estuarine system showing the main tributaries (Garonne, Dordogne) and the four instrumented sites (red squares): Libourne, Portets, Bordeaux and Pauillac. Graduations indicate the kilometric distance from Bordeaux city (SOMLIT stations: PK30, PK52, PK67, PK82; see Saari el al., 2010 for details). The lines show the navigation and the Saintonge channels in the estuary.

\section{Description of the high-frequency monitoring network of the Gironde}

\subsection{The Gironde fluvial-estuarine system}

The Gironde watershed $\left(71000 \mathrm{~km}^{2}\right)$ is formed by the Garonne River (comprising 65\% of the freshwater input) and Dordogne River (35\% of the fresh water input) (Fig. 1). It is a partially mixed to well-mixed macrotidal estuary with tidal amplitudes from 1.5 to $5 \mathrm{~m}$ at the mouth. The depth ranges between 5 and $8 \mathrm{~m}$ in the upper estuary and can reach up to $20 \mathrm{~m}$ in the lower estuary (Fig. 1; Sottolichio and Castaing, 1999). During one tidal cycle, the ocean inputs are 30-40x greater than the freshwater inputs (Allen et al., 1977). The tidal wave propagates $180 \mathrm{~km}$ upstream from the mouth (Sottolichio and Castaing, 1999). The tidal amplitude increases progressively towards the upper estuary, reaching its maximum value at $120 \mathrm{~km}$ from the mouth before decaying in the fluvial narrow sections. Therefore the Gironde is described as a hypersynchronous estuary following the classification of Le Floch (Allen et al., 1980). The upstream limits for the dynamic tidal zone are: La Réole for the Garonne River, Pessac for the Dordogne River and Guîtres for the Isle River (Fig. 1). 
The Gironde Estuary is marked by a pronounced turbidity maximum zone (TMZ) resulting from the asymmetry of the tidal wave when propagating upstream, coupled to density residual circulation. The seasonal variability of SPM of estuarine waters is remarkable, with values ranging between 0.1 and $10 \mathrm{~g} \mathrm{~L}^{-1}$. In the core of the $\mathrm{TMZ}$, suspended particulate matter (SPM) concentrations in surface water are always higher than $1 \mathrm{~g} \mathrm{~L}^{-1}$ (Castaing and Allen, 1981). The main parameters controlling SPM transport in and out of the Gironde Estuary are river flow and tidal currents, modulated by tidal range. During slack water periods, mainly on neap tides, suspended matter settling is enhanced and fluid mud $\left(\mathrm{SPM}>100 \mathrm{~g} \mathrm{~L}^{-1}\right)$ appears on the channel bottom, forming elongated patches of $10-15 \mathrm{~km}$ length and $2 \mathrm{~m}$ thick, with concentrations up to $300 \mathrm{~g} \mathrm{~L}^{-1}$ (Sottolichio and Castaing, 1999). The turbidity maximum zone moves along the estuary depending on horizontal tidal excursions and changes of fluvial discharge. During the period of low discharge (MayNovember) the TMZ moves up-estuary, oscillating between PK30 and Portets and Libourne (Fig. 1); in contrast, during high fluvial discharge (December-May) the TMZ moves down-estuary (between stations PK30 and PK67; Fig. 1) (Allen et al., 1977; Saari et al., 2010). TMZ particles present a low particulate organic carbon content (POC, $1.5 \pm 0.1 \%$ ) and lability (Etcheber et al., 2007). Only 10\% of POC is autochthonous (phytoplankton), with primary production being strongly light-limited and thus reduced in this turbid system.

\subsection{Strategy of the long-term monitoring}

The main objective of the MAGEST monitoring is to better quantify the impact of the TMZ and of changes on land use on the dissolved oxygen content and the related risks of asphyxia of biological communities. This survey will permit to acquire reliable and detailed time-series under different hydrologic regimes in order to understand factors involved in oxygen consumption. Such knowledge is essential to predict the evolution of water quality of the Gironde fluvial-estuarine system in response to climate and environment forcing.

We have selected four parameters to characterize water quality: temperature, salinity, turbidity and dissolved oxygen. Temperature and salinity are reliable parameters and representative of the hydrologic conditions (marine intrusion, riverine discharges, seasons). Turbidity is a key parameter of the Gironde Estuary: it is a good tracer of the hydrodynamic. Dissolved oxygen content is a direct indicator of the water quality.

To optimize the survey, four stations have been selected as representative of the estuarine waters (Fig. 1). The first station is Pauillac: it is located $52 \mathrm{~km}$ downstream Bordeaux. It is considered as a reference of the central estuary. The second station is Bordeaux, considered as an urban one: it is located in a large agglomeration of nearly 1 million of inhabitants. The two last stations are situated in the fluvial estuary, Libourne on the Dordogne and Portets on the Garonne re- spectively: they are likely to register the riverine inputs. The present network does not include, for instance, a station at the mouth. Considering the acquisition (about 100 keuros) and operating (about 10-15 keuros per year) budgets of one station, the equipment of the mouth was not considered as a priority. First the problem of episodic hypoxia occurs in the fluvial section. Secondly there is a previously existing long-term survey, SOMLIT (Service d'Observation en Milieu Littoral, INSU-CNRS; David et al., 2005), in the down and central Gironde Estuary. Since 1978, temperature, salinity, SPM, dissolved oxygen, chlorophyll and pheopigment are measured 10 times per year from surface and bottom waters at four stations (Fig. 1) during one tidal cycle.

The two network are complementary, although with slightly different purposes. SOMLIT is a national survey program of coastal waters to collect long-term series of ecosystem changes. The MAGEST network is more focused on the link between the estuary and the watershed: the objectives are not only to record changes in water quality, but also to offer an operational high-frequency tool for water quality management. This explains the choice of the stations: MAGEST being located in the central and fluvial estuary; SOMLIT in the central and down estuary. The central estuary is common with station PK52 in channel waters for SOMLIT, and Pauillac on the riverbank for MAGEST (Fig. 1). A recent comparison exercise had showed a good agreement between the two data series for temperature and salinity (Ben Mustapha, 2010). Turbidity values are less comparable between the two datasets (PK52, Pauillac). This could be in relation with the localization. But the main explanation is likely the high heterogeneity of this parameter. Nevertheless turbidity values of both survey agree for the occurrence or not of the turbidity maximum zone in the central estuary.

\subsection{The MAREL automated stations}

The four sites of the MAGEST network are instrumented with a real-time measurement system of selected water parameters: temperature, salinity, turbidity and dissolved oxygen (Fig. 2). The first implemented station was Pauillac in the central estuary, the 15 June 2004. Acquisition at Portets and Libourne stations had begun the 16 November 2004 and at Bordeaux station the 16 March 2005.

The stations were installed on previously existing floating landing stages. This choice was different from previous MAREL systems, on the Seine river (Woerther, 2002; Dur et al., 2007; Schmitt et al., 2008) and in the rade de Brest (Blain et al., 2004), based on anchored buoys away from the banks. Our main criteria were the needs for protection of the system in a highly dynamic system (river floods often carry large branches or trunks in the axis of the channel) but also an easier access in case of breakdown. The architecture of the monitoring system, so-called MAREL, consists in an autonomous measuring system, a bi-directional telecommunication link using 


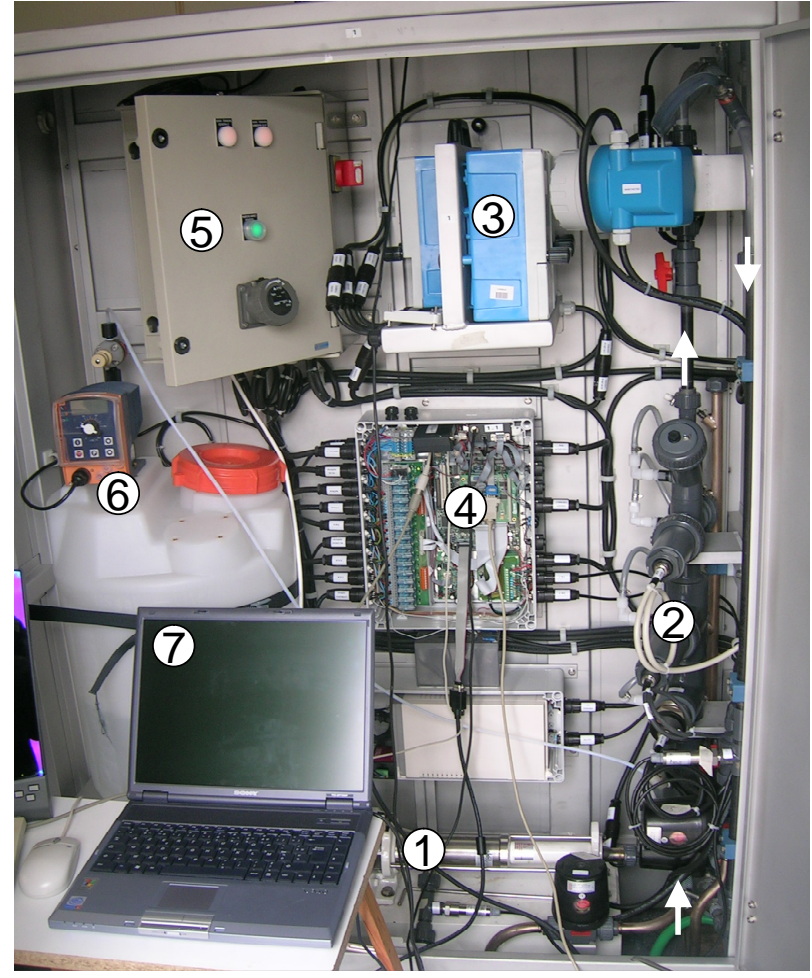

Fig. 2. Sketch of the MAGEST automated station showing the main parts of the measuring system: (1) the pump, (2) the measuring cell, (3) the transmission system, (4) measurement and control electronic system, (5) the electric power supply, and (6) the antifouling system. Arrows underline water circulation. Labtop (7) can be directly connected for on field maintenance. The dimensions of a station are roughly $0.8 \mathrm{~m}$ in width, $1.8 \mathrm{~m}$ in height, and $0.5 \mathrm{~m}$ in thickness.

Internet protocol, and a land-based management station for collection (http://marelgironde.geocean.u-bordeaux.fr/ dif/index.htm), processing and database of quality-controlled data. Waters are pumped $1 \mathrm{~m}$ below the surface, and circulate through a measuring cell including water temperature, conductivity, turbidity, dissolved oxygen (Fig. 2). The sensors for conductivity (INDUMAX CLS 52), temperature (Pt 100 included in INDUMAX), oxygen (OXYMAX W COS 41) and turbidity (TURBIMAX W CUS 31) are manufactured by Endress and Hauser (Germany). The measuring unit is adapted to riverine and coastal conditions. The sensors are able to work on field conditions over long periods, without important drifts in measured values (Maneux et al., 2010). The temperature sensor covers a range from 0 to $35^{\circ} \mathrm{C}$, with an accuracy of $0.1{ }^{\circ} \mathrm{C}$. The turbidity sensor measures values between 0 and 9999 NTU, with a precision of $10 \%$ on the value; 9999 NTU correspond to about $12 \mathrm{gL}^{-1}$. The oxygen sensor range is $0-20 \mathrm{mg} \mathrm{L}^{-1}\left( \pm 0.2 \mathrm{mg} \mathrm{L}^{-1}\right)$. Only the range of conductivity sensors was different depending of the considered station. At Pauillac and Bordeaux, the most marine stations, the sensor covers a range from 0 to $70 \mathrm{mS} \mathrm{cm}^{-1}$ $\left( \pm 0.3 \mathrm{mS} \mathrm{cm}^{-1}\right)$. The sensors in used at Portets and Libourne, in the fluvio-estuarine section, have a lower range $\left(0-2 \mathrm{mS} \mathrm{cm}^{-1}\right)$ but a higher precision $\left(0.1 \mathrm{mS} \mathrm{cm}^{-1}\right)$. The salinity is expressed using the UNESCO Practical Salinity Scale of 1978. An ultrasonic level controller measures the water depth of the river.

Recorded data correspond to instantaneous values that are measured every $10 \mathrm{~min}$, and transmitted to a dedicated website of the University of Bordeaux (http://www.magest. u-bordeaux 1.fr). The station is equipped with a cellular GSM transmission system to transmit the data to the web server. The Web data are updated every six hours. In case of communication failure, there is an automatically generated alarm to the users. A preliminary diagnosis is possible through the remote control of the in situ station. These real-data are complemented with two operations to ensure data quality. The first operation consists in checking on the 3-month basis the in situ system; the second in calibrating the associated sensors to validate the data-series.

\section{Results and discussion}

\subsection{Overview on station functioning}

From 2005, the MAGEST network had allowed the acquisition of the equivalent of about 45 months per station, which corresponds to about $75 \%$ of time in service. In 5 years, MAGEST had produced more than one million of data documenting the water quality of the Gironde Estuary. Functioning rate and the percentage of validated data are followed monthly per station. By example, Bordeaux in 2008 worked very well in May, June and June ( $>95 \%$ ), but failed in July and November (about 35\%). The most reliable sensors are those of temperature and conductivity, and to a less extend turbidity. Dissolved oxygen determination is trickier.

Missing data are related to different possible origins. The first problem is the electricity supply from the landing stages, managed by other organizations. Power cuts are unpredictable and could be related to accidents or local renovation work. The second difficulty is the maintenance of the stations, which are subject to severe environmental conditions: strong currents, high turbidity, moisture, heat/cold in summer/winter. These conditions could induce sensor malfunction (in particular for the turbidity one) or spare breakage. Such automated stations require in fact a reliable follow-up work to ensure the acquisition of high quality data.

In the following, we do not plan to detail the whole dataset, which is available on the website. Through examples, we only illustrate main trends in changes of the measured parameters (temperature, salinity, turbidity, dissolved oxygen) from tidal to seasonal time scales. Thereafter we have selected two peculiar records, which show the interest of high frequency survey, in order to demonstrate the interest of such monitoring in large fluvial-estuarine systems as a tool of long-term management. 

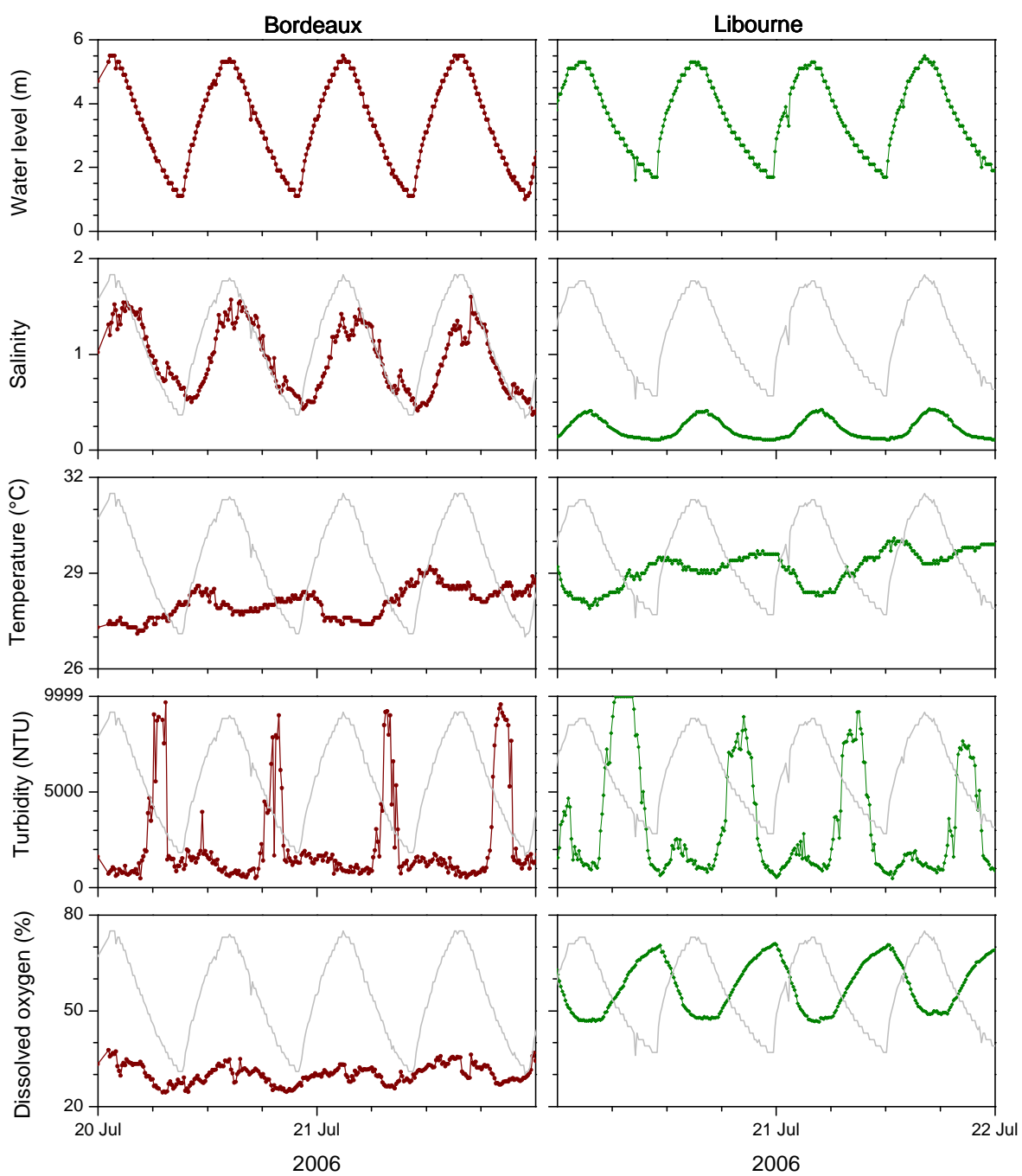

Fig. 3. Example of variations of water level (m), salinity, temperature $\left({ }^{\circ} \mathrm{C}\right)$, turbidity (NTU) and dissolved oxygen $(\%$ of saturation) during consecutive semi-diurnal tidal cycles at stations Bordeaux (left) and Libourne (right) from 20 to 22 July 2006 (data every 10 min). Corresponding water level curves (in light grey) are reported on each graph to highlight the relationship between the measured parameters and tidal cycle.

\subsection{Tidal influence on hydrological parameters}

The most characteristic signal in an estuarine system is the semi-diurnal tidal cycle. Figure 3 illustrates variations of salinity, temperature, turbidity, and dissolved oxygen during consecutive tidal cycles at Bordeaux and Libourne. The example corresponds to the dataset from 20 to 22 July 2006, representative of a summer situation. There is a minor time lag in ebb, recorded by the water level, between the two stations (Fig. 3): this is related to the respective distances of these two stations from the mouth, and the tidal propagation, Libourne being the most distant (Fig. 1). Salinity and temperature record always marine intrusion. Salinities are the highest at the end of the flood phase. Salinity variation is more pronounced in Bordeaux, the downward station: salin- ity range between about 0.5 and 1.5 for the situation recorded end July 2006. Upward, at Libourne, salinity is always $<0.5$. It should be noted that salinity are nearly null in Libourne, and Portets, during high discharge periods. For the situation end July, temperature presents increasing values, superimposed to tidal signal, as expected in summer (Fig. 3). Marine intrusion of temperate waters acts as a regulator of temperature. This explains temperature difference between Bordeaux and Libourne: Bordeaux still benefits from cooling effect at high tides. By comparison, Libourne waters are about $+1{ }^{\circ} \mathrm{C}$ warmer, due to river influence.

Turbidity shows the typical pattern of the erosiondeposition cycle observed in macrotidal estuaries (Allen et al., 1980; Castaing and Allen, 1981; Uncles et al., 2010). As expected end July, riverine discharges are low and TMZ 
moves upstream. Both stations record high turbidity in surface waters, with a minimum value of $1.2 \mathrm{~g} \mathrm{~L}^{-1}$ at low tide. Furthermore, two distinct SPM peaks are observed at midflood and mid-ebb respectively, due to resuspension by tidal currents. However, a strong asymmetry is observed in absolute values, with a significantly higher peak at ebb than flood. This is explained by the joint effects of changes in cross section and in relative depth of the sampling water during the tidal cycle. During flood resuspension phase, increase of turbidity is limited by dispersion/dilution favored by enlarging cross section; while during ebb phase, the sampling point gets closer to the bottom and to the tidal flat, generating relative increase of SPM concentration.

Along with the high SPM levels, dissolved oxygen is significantly undersaturated, especially at Bordeaux where values ranged between 25 and $40 \%$. But variations of dissolved oxygen with ebb cycle are different between the two stations. At Libourne the highest oxygen levels, $70-75 \%$, are observed at low tide; the lowest, $45-50 \%$, at high tide. Surprisingly, station Bordeaux records the opposite signal: the lowest oxygen levels, $<30 \%$, are observed at the end of low tide. This result will be discussed in Sect. 3.4.

\subsection{Seasonal trends in the different sections of the Gironde Estuary}

High-frequency data are not appropriate to bring out seasonal changes in hydrological parameters as a function of their localization in the estuary. Monthly-averaged temperature, salinity, turbidity and dissolved oxygen saturation have been calculated for each station from January 2005 to Octobre 2006 (Fig. 4). Two hydrological cycles are plotted (Fig. 4). Missing data correspond to acquisition interruption due to technique problem of the considered automated station.

Temperature ranges between 5 to about $25^{\circ} \mathrm{C}$, and presents a well defined seasonal signal. It shows negligible differences throughout the estuary and appears as a common characteristic. This parameter registers regional climatology, rather local signal. On the opposite, salinity, turbidity and dissolved oxygen present contrasted signals among stations.

\subsubsection{The central estuary: Pauillac}

In the central estuary, Pauillac show the highest salinities: from 2-4 in winters (when river discharges are the highest) to about 10 during summer low-level waters. Turbidity values are elevated throughout the year; but they present a narrow range of variation, from few hundreds $\mathrm{mg} \mathrm{L}^{-1}$ to about $2 \mathrm{gL}^{-1}$. This testifies of the nearly permanent presence of TMZ in the central estuary. Waters remain well oxygenated whatever the season, with values from 80 to $95 \%$ of saturation. During low-level waters, when TMZ is pushed in the upper estuary, suspended load is reduced and oxygen saturation is the highest.

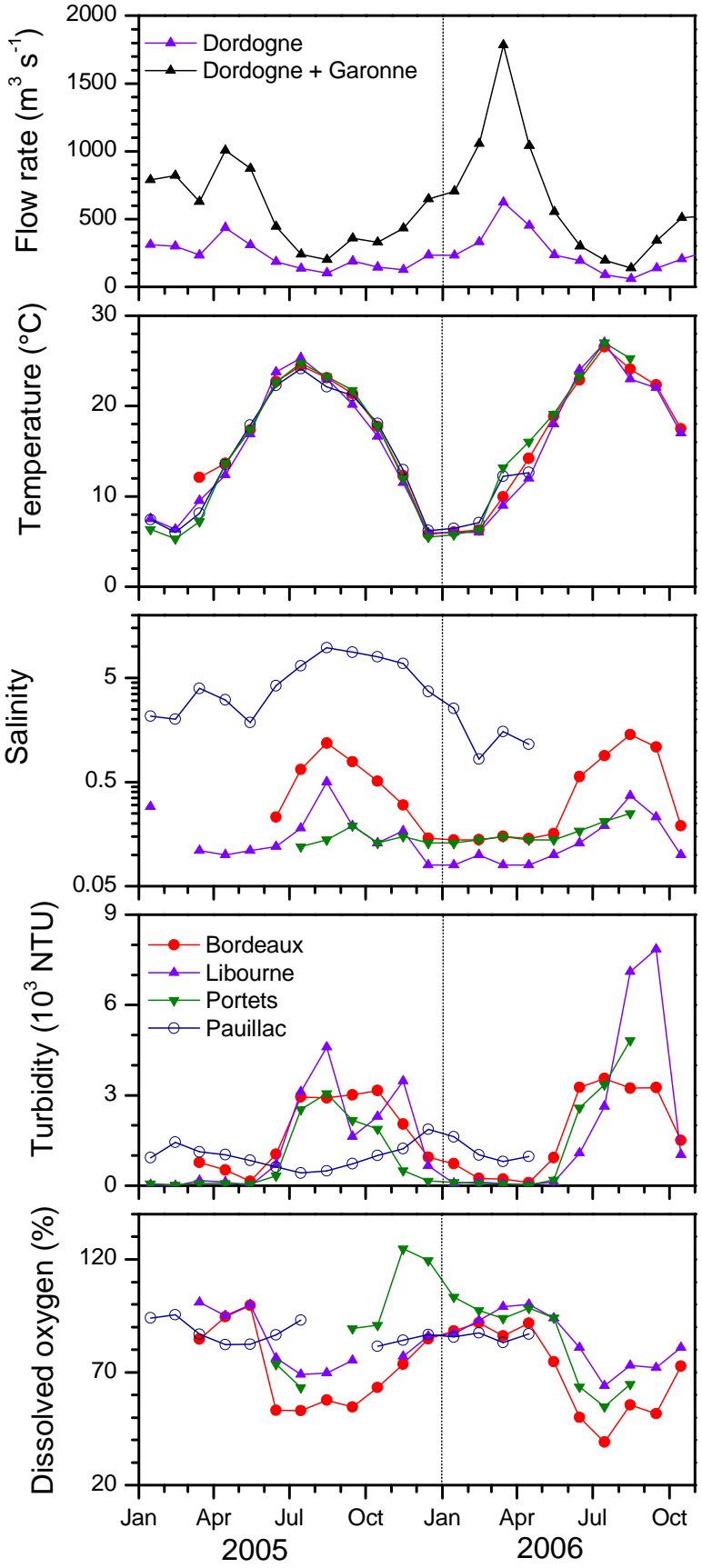

Fig. 4. Comparison of monthly changes in flow rate $\left(\mathrm{m}^{3} \mathrm{~s}^{-1}\right)$, temperature $\left({ }^{\circ} \mathrm{C}\right)$, salinity, turbidity $\left(10^{3} \mathrm{NTU}\right)$ and dissolved oxygen (\% of saturation), from January 2005, to October 2006, among the stations Bordeaux (circles), Libourne (up-triangles), Portets (downtriangles) and Pauillac (circles) of the MAGEST network.

\subsubsection{The fluvial estuary: Libourne, Portets, Bordeaux}

Except for temperature, water characteristics are different in the upper estuary (Fig. 4). Bordeaux, the downstream station of the fluvial estuary, could register salinity up to 1.2 in summer, when river discharge is the lowest. Not surprisingly, 


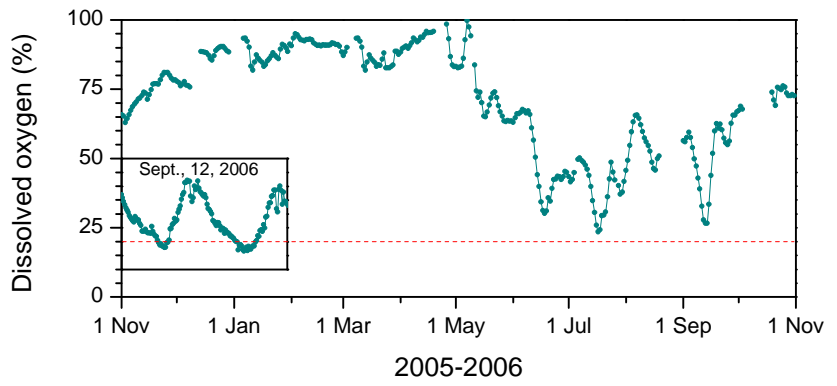

Fig. 5. Temporal evolution of daily-average dissolved oxygen saturation (\% of saturation), from November 2005 to October 2006, at the station Bordeaux. The inset corresponds to a zoom of the curve centered on the 12 September 2006, showing the detailed data (every $10 \mathrm{~min}$ ); the Y scale is the same as the one of the main graph; the dashed line underlines dissolved oxygen saturation of $20 \%$.

the two up-estuary stations, Portets and Libourne, record the lowest salinity range. However Libourne waters present salinities up to 0.5 in summer. This points out a more pronounced marine intrusion in Libourne, compared to Portets.

In the fluvial estuary, turbidity shows a larger range than the one observed in the central estuary, from low values in winter up to $6-8 \mathrm{~g} \mathrm{~L}^{-1}$ in summer. Trend in seasonal evolution of turbidity in the fluvial estuary is therefore the opposite of those observed in the central estuary. This is explained by the longitudinal translation of TMZ along the estuarine axis in relation to hydrological context. High river discharges in winter flush TMZ downstream, whereas marine intrusion push it upstream (Allen et al., 1980; Castaing and Allen, 1981).

Dissolved oxygen saturations in Bordeaux, Libourne and Portets are comprised between 40 to nearly $100 \%$ and show a larger variability than observed in Pauillac. There is a noticeable decrease of saturation in June to reach the low summer levels. The lowest monthly saturation are simultaneous to the highest monthly turbidity: this confirms the impact of oxygen consumption associated with the TMZ particles. However the highest turbidities are recorded at Libourne, whereas the lower oxygen saturations are encountered in Bordeaux.

\subsection{Trend in oxygen saturation of waters in the vicinity of a large city}

Whatever the considered time scale, tidal cycle or season (Fig. 5), Bordeaux presents systematically different signals in dissolved oxygen, compared to the other stations (Fig. 4). Dissolved oxygen saturation of estuarine waters is influenced by several biogeochemical parameters: primary production, organic matter degradation, nitrification, eddy exchanges (Morris et al., 1982; Irigoien et al., 1999; Attrill and Power, 2000; van Vliet and Zwolsman, 2008). The maximum turbidity zone is a natural reactor which promotes organic matter degradation. In the fluvial section of the Gironde Estuary, dissolved oxygen saturation decreases when suspended particle load becomes higher to $1-2 \mathrm{~g} \mathrm{~L}^{-1}$ (Fig. 4). The saturation rates of 50-70\% recorded at Libourne and Portets in summer well illustrate this process.

In Bordeaux, this parameter shows the lowest levels of the monitoring in summer (Fig. 5). It was previously noted a different behavior of oxygen at Bordeaux, compared to Libourne, during the semi-diurnal tidal cycle: the lowest oxygen saturation and turbidity occur simultaneously at low tide (Fig. 3). Figure 5 presents daily variations of oxygen saturation at Bordeaux: the oxygen minimum is more pronounced for marked low-water level. More in detail, the continuous record shows critical values, $<20 \%$, can be reached during ebb phase (Fig. 5). We hypothesize that it is related to a local input of labile organic matter. Indeed Bordeaux and its suburbs are a major source of probably organic - rich wastes. At low tides in summer, these discharges are delivered in warm and low-level waters, and may be degraded under oxygen consumption. During high tide, the intrusion of marine and oxygenated waters builds up oxygen saturation.

\subsection{Rupture of the Tuilières dam on 29 January 2006}

The Gironde watershed is characterized by the presence of numerous dams to produce power supply. The Dordogne River and its tributaries have about 60 dams, mainly in their upper reaches in the Massif Central. Three of them are located in the lower Dordogne; in particular the Tuilières dam, about $80 \mathrm{~km}$ upstream Libourne. Built in 1908, it is equipped of eight large gates, of $13 \mathrm{~m}$ in height and 7 in width. A gate failed at 03:00 a.m. on January 2006, causing the emptying of the dam reservoir. About $5 \times 10^{6} \mathrm{~m}^{3}$ were thus released in few hours into the Dordogne river (Epidor, 2006) leading to a rise in flow rate from 140 to $480 \mathrm{~m}^{3} \mathrm{~s}^{-1}$ downstream. Raging flows created a water swell of about $+1.5 \mathrm{~m}$ at $2 \mathrm{~km}$ and $+0.9 \mathrm{~cm}$ at $13 \mathrm{~km}$. Fortunately damages were limited due to the very low flow rate of the Dordogne at that time, $140 \mathrm{~m}^{3} \mathrm{~s}^{-1}$ (instead $465 \mathrm{~m}^{3} \mathrm{~s}^{-1}$ ).

On a water quality aspect, such a flash flood induced by a dam rupture is likely to erode sediments from the river bed and banks, in the limit of the water height. There were obvious visual impacts within the $10 \mathrm{~km}$ below the dam, like boats perched above the river, garbage and flood deposits. The instrumented station of Libourne had offered the opportunity to investigate the impact of the accident on a wider scale.

Temporal evolution of turbidity along with flow rates and water level is shown for the period from 25 January, to 10 February 2006, encompassing the time of the rupture (Fig. 6). Temperature is low, about $4-5^{\circ} \mathrm{C}$, in agreement with a winter situation. Salinity is rather negligible, as Libourne is located in the upper estuary. There is although a well marked tidal cycle in the water level. As previously mentioned, water discharge is low; far below the values $>400 \mathrm{~m} \mathrm{~s}^{-1}$ usually observed in January. From 25 to 28 January, the river 


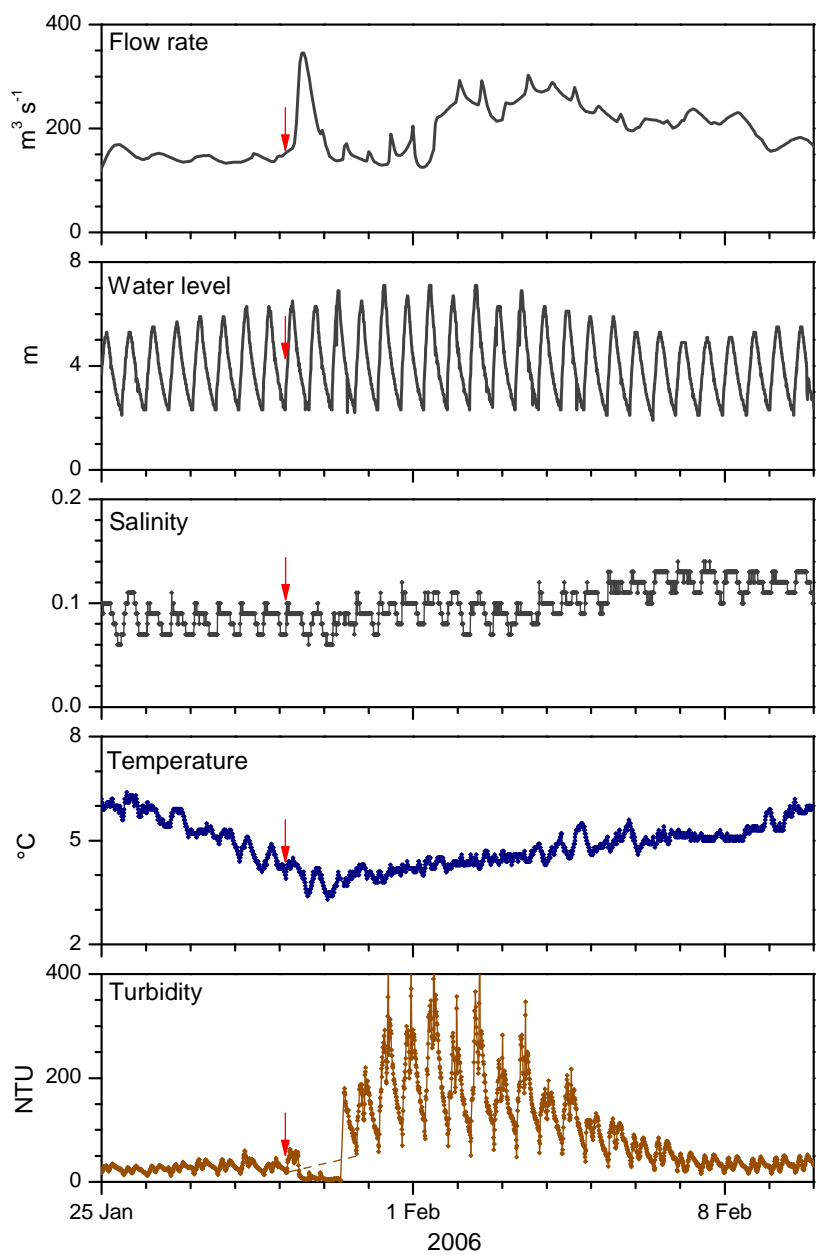

Fig. 6. Temporal evolution of flow rate $\left(\mathrm{m}^{3} \mathrm{~s}^{-1}\right)$, water level $(\mathrm{m})$, salinity, temperature $\left({ }^{\circ} \mathrm{C}\right.$ ) and turbidity (NTU) from 25 January to 10 February 2006 at the station Libourne on the Dordogne river. The arrows point out the time of the dam rupture. The dashed line (lower panel) simulates the expected increase in turbidity minimum.

discharge $>100 \mathrm{~m} \mathrm{~s}^{-1}$ along with the low tidal range limit the upward marine intrusion. On 29 January, at about 10:00 a.m., i.e. $6 \mathrm{~h}$ after the gate rupture, there is an abrupt increase in flow rate: the duration of this event is about half a day. This is associated with a slight decrease in salinity and temperature, down to 0.07 and $3.4^{\circ} \mathrm{C}$ respectively. But the most obvious feature is the collapse of turbidity, from about $0.1 \mathrm{~g} \mathrm{~L}^{-1}$ to negligible levels. Unexpectedly there is no record of enhanced turbidity associated with the water swell. An explanation could be a rapid settling of resuspended sediment between the dam and Libourne, both separated by about $80 \mathrm{~km}$ : flood deposits, dominated by sand, were observed within 10 $15 \mathrm{~km}$ downstream from the dam (Epidor, 2006). In fact the fast release of a large water volume had leaded to a temporary dilution of supended particles concentration. Early February there was then a significant increase of turbidity. This signal is observed after the record of the swell, and is not related to the dam rupture. Indeed the spring tides were early February: tidal range was the highest the 1 February (ebb coefficient of 107). Turbidity increase was ascribed to the hydrodynamic of the estuary. This explains the increasing turbidity values at high water until early February; thereafter turbidity peaks decreased to values observed end January.

This example illustrates the ability of high frequency monitoring to record peculiar events. In fact a decrease in turbidity associated with the dam rupture was not expected: intuitively one would expect the opposite result. This could be explained by the distance $(80 \mathrm{~km})$ between the dam and the nature of sediments. By improving knowledge of sediment dynamic, this outstanding result is of valuable interest for further developments of the Dordogne River.

\section{Conclusions}

The monitoring of the Gironde Estuary through the MAGEST network confirms the general trend in annual variations of the four selected parameters (temperature, salinity, turbidity, dissolved oxygen). The common characteristics of the stations are a temporal evolution of temperature in relation with season, the maximum being recorded in summer. The others parameters are more variable among the four stations depending of their localization: marine or fluvial section, urban impact. In addition to these general trends, the time-series had allowed to highlight inter-annual variability in relation with the local meteorology; 2005 and 2006 being rather dry and hot, at the difference of the following years. Such observations are crucial for further interpretations of time-series and to extract tendencies in long-term evolution. It would contribute to better understand the functioning of the Gironde Estuary and to extract potential tendencies in addition to interannual variability and to register the possible effects of human activities and of changing climate on the water and ecological quality of the Gironde Estuary. The four stations are currently working, the objective is now to complete in the near future this network by a station at the mouth to obtain a high-frequency permanent observatory of the whole estuary.

This database clearly illustrates the interest of high frequency monitoring of water quality in estuaries, based on in situ instrumented sites. Although the critical need of a good knowledge of ecosystem functioning and quality in transient waters, the use of real-time continuous systems is not common in estuarine system (Garel et al., 2009; Reuter et al., 2009). Though it can not eliminate manual samples and/or measurements, the benefit of such monitoring is large, when the strategy relies on an appropriate diagnostic of the system (Brierly et al., 2010). The continuous measurement of selected parameters offers the opportunity to record specific and unpredictable events, like a storm or a flood event, that are difficult to sample. It provides more reliable datasets to produce mean yearly values than a dataset based on a 
monthly sampling by example. The use of such data series is of significant interest to progress in estuarine sciences and management, and need to be developed in estuaries. By example, it could contribute in improving the concepts on sediment dynamics required to develop numerical models for predicting estuarine evolution, as underlined in the introduction to the special issue dedicated to the Mechanisms of Sediment Retention in Estuaries (SCOR/LOICZ/IAPSO Working Group 122) (Perillo and Syvitski, 2010).

Acknowledgements. This work is financially supported by the following organisms: AEAG (Agence de l'Eau Adour-Garonne); SMIDDEST (Syndicat MIxte pour le Développement Durable de l'ESTuaire de la Gironde); SMEAG (Syndicat Mixte d'Etudes et d'Aménagement de la Garonne); EPIDOR (Etablissement Public Interdépartemental de la Dordogne); EDF; GPMB (Grand Port Maritime de Bordeaux); Conseil Régional Aquitaine; CG-33 (Conseil Général de Gironde); Ifremer; CNRS; Université Bordeaux 1. The authors thank also the support of the OASU (Observatoire Aquitain des Sciences de l'Univers) through the SOLAQUI (Service d'Observation du Littoral AQUItain) program. The authors thank G. M. E. Perillo and an anonymous for constructive comments.

\section{Edited by: A. D. Reeves}

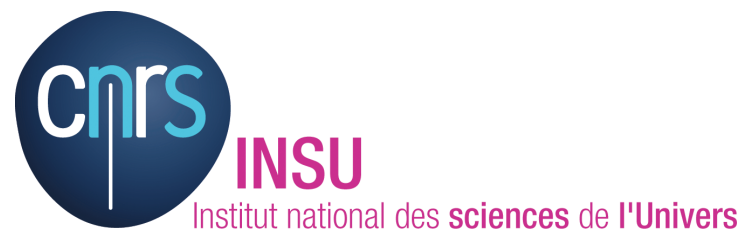

The publication of this article is financed by CNRS-INSU.

\section{References}

Abril, G., Nogueira, M., Etcheber, H., Cabeçadas, G., Lemaire, E., and Brogueira, M. J.: Behaviour of organic carbon in nine contrasting European estuaries, Estuar. Coast. Shelf Sci., 54, 241262, 2002.

Alcamo, J., Flörke, M., and Märker, M.: Future long-term changes in global water resources driven by socioeconomic and climatic change, Hydrol. Sci. J., 52, 247-275, 2007.

Allen, G. P, Sauzay, G., Castaing, P., and Jouanneau, J. M.: Transport and deposition of suspended sediment in the Gironde Estuary, France, in: Estuarine Processes, New York: Academic Press, edited by: Wiley, M., 63-81, 1977.

Allen, G. P., Salomon, J. C, Bassoullet, P., Du Penhoat, Y., and De Grandpré, C.: Effects of tides on mixing and suspended sediment transport in macrotidal estuaries, Sedim. Geol., 26, 69-90, 1980.

Attrill, M. J. and Power, M.: Modelling the effect of drought on estuarine water quality, Wat. Res., 34, 1584-1594, 2000.

Baborowski, M., von Tümpling, jr., W., and Friese, K.: Behaviour of suspended particulate matter (SPM) and selected trace metals during the 2002 summer flood in the River Elbe (Germany) at Magdeburg monitoring station, Hydrol. Earth Syst. Sci., 8, 135150, doi:10.5194/hess-8-135-2004, 2004.
Ben Mustapha, Z., Etcheber, H., and Sautour, B.: Contribution des réseaux SOMLIT GIRONDE et MAGEST à l'étude de l'évolution de la qualité physico-chimique des eaux de l'estuaire de la Gironde. Contribution of the SOMLIT GIRONDE and MAGEST networks to the study of changes in water quality of the Gironde Estuary. 26 ${ }^{\text {th }}$ Forum des Jeunes Océanographes, 30 Sep-1 Oct, Wimereux, France, 2010.

Blain, S., Guillou, J., Tréguer, P., Woerther, P., Delauney, L., Follenfant, E., Gontier, O., Hamon, M., Leildé, B., Masson, A., Tartu, C., and Vuillemin, R.: High frequency monitoring of the coastal marine environment using the MAREL buoy, J. Environ. Monit., 6, 569-575, 2004.

Borja, Á., Dauer, D. M., Elliott, M., and Simenstad, C. A.: Mediumand Long-term Recovery of Estuarine and Coastal Ecosystems: Patterns, Rates and Restoration Effectiveness, Estuar. Coasts, 33, 1249-1260, 2010.

Boyer, C., Verhaar, P. M., Roy, A. G., Biron, P. M., and Morin, J.: Impacts of environmental changes on the hydrology and sedimentary processes at the confluence of St. Lawrence tributaries: potential effects on fluvial ecosystems, Hydrobiol., 647, 163183, 2010.

Brierley, G., Reid, H., Fryirs, K., and Trahan, N.: What are we monitoring and why? Using geomorphic principles to frame eco-hydrological assessments of river condition, Sci. Total Envir., 408, 2025-2033, 2010.

Castaing, P. and Allen, G. P.: Mechanisms controlling seaward escape of suspended sediment from the Gironde: a macrotidal estuary in France, Mar. Geol., 40, 101-118, 1981.

David, V., Sautour, B., Chardy, P., and Leconte, M.: Long-term changes of the zooplankton variability in a turbid environment: The Gironde estuary (France), Estuar. Coast. Shelf Sci., 64, 171184, 2005.

Dur G., Schmitt F. G., and Souissi S.: Analysis of high frequency temperature time series in the Seine estuary from the Marel autonomous monitoring buoy, Hydrobiol., 588, 59-68, 2007.

Epidor, Rupture du barrage de Tuilières: diagnostic environmental de la rivière Dordogne entre Lalinde et Tuilières, http://www. eptb-dordogne.fr/documentation/index.php?module=5, 2006.

Etcheber, H., Taillez, A., Abril, G., Garnier, J., Servais, P., Moatar, F., and Commarieu, M.V.: Particulate organic carbon in the estuarine turbidity maxima of the Gironde, Loire and Seine estuaries: origin and lability, Hydrobiol., 588, 245-259, 2007.

Garel, E., Nunes, S., Neto, J. M., Fernandes, R., Neves R., Marques, J. C., and Ferreira, Ó.: The autonomous Simpatico system for real-time continuous water-quality and current velocity monitoring: examples of application in three Portuguese estuaries, Geo.-Mar. Lett., doi:10.1007/s00367-009-0147-5, 2009.

Hoffmann, T., Thorndycraft, V. R., Brown, A. G., Coulthard, T. J., Damnati, B., Kale, V. S., Middelkoop, H., Notebaert, B., and Walling, D. E.: Human impact on fluvial regimes and sediment flux during the Holocene: Review and future research agenda, Global Planet. Change, 72, 87-98, 2010.

Horowitz, A. J.: Monitoring suspended sediments and associated chemical constituents in urban environments: lessons from the city of Atlanta, Georgia, USA Water Quality Monitoring Program, J. Soils Sediments, 9, 342-363, 2009.

Irigoien, X., Post, J., Castel, J., Pfeiffer, P. F., and Hellmann, B.: Nycthemeral variations of the dissolved oxygen concentration in the turbidity maximum of three European estuaries: biological 
vs. physical processes, J. Mar. Sys., 22, 173-177, 1999.

Jouanneau, J. M., Weber, O., Cremer, M., and Castaing, P.: Finegrained sediment budget on the continental margin of the Bay of Biscay, Deep-Sea Res. II, 46, 2205-2220, 1999.

Johnson, A. C., Acreman, M. C., Dunbar, M. J., Feist S. W., Giacomello, A. M., Gozlan R. E., Hinsley S. A., Ibbotson A. T., Jarvie H. P., Jones J. I., Longshaw, M., Maberly, S. C., Marsh, T. J., Neal, C., Newman, J. R., Nunn, M. A., Pickup, R. W., Reynard, N. S., Sullivan, C. A., Sumpter, J. P., and Williams, R. J.: The British river of the future: How climate change and human activity might affect two contrasting river ecosystems in England, Sci. Tot. Envir., 407, 4787-4798, 2009.

Latouche C.: Cadmium pollution in the Gironde estuary, Bull Inst Géol Bassin Aquitaine, 44, 15-21, 1988.

Maneux E., Castaing P., Chabaux G., Escalier J.-M., Etcheber H., Schmeltz M., Schmidt S., and Woerther P., MAGEST: Surveillance en continu pour la connaissance de la qualité des eaux de l'estuaire de la Gironde, Actes Journées Nationales Génie Côtier - Génie Civil Edition 11, Les Sables d'Olonne, 521-528, doi:10.5150/jngcgc.2010.061-M, 2010.

Meybeck, M. and Helmer, R.: The quality of rivers: from pristine stage to global pollution, Paleogeogr. Paleoclim. Paleoecol., 75, 283-309, 1989.

Morris A. W., Loring D. H., Bale A. J., Howland R. J. M., Mantoura R. F. C., and Woodward E. M. S.: Particle dynamics particulate carbon and the oxygen minimum in an estuary, Oceanol. Acta., 5, 349-353, 1982.

Neal, C.: The water quality functioning of the upper River Severn, Plynlimon, mid-Wales: issues of monitoring, process understanding and forestry, Hydrol. Earth Syst. Sci., 8, 521-532, doi:10.5194/hess-8-521-2004, 2004.

Perillo, G. M. E, Syvistki, J. P. M., Amos, C. L., Depetris, P., Milliman, J., Pejrup, M., Saito, Y., Snoussi, M., Wolanski, E., Zajaczkowski, M., Stallard, R., Hutton, E., Kettner, A., Meade, R., Overeem, I., and Peckham, S.: Estuaries and the sediments: how they deal with each other, LOICZ INPRINT 2007-3, 3-5, 2007.

Perillo, G. M. E. and Syvitski, J. P. M.: Mechanims of sediment retention in estuaries, Estuar. Coast. Shelf Res., 87, 175-176, 2010.

Reuter R., Badewien T. H., Bartholomä B. A., Lübben A., and Rullkötter J.: A hydrographic time series station in the Wadden Sea (southern North Sea), Ocean Dynamics, 59, 195-211, 2009.

Sabater, S. and Stevenson, R. J.: Foreword: Global change and river ecosystems - implications for structure, function, and ecosystem services, Hydrobiol., 657, 2010.

Saari, H.-K., Schmidt, S., Coynel, A., Huguet, S., Schäfer, J., and Blanc, G.: Potential impact of former $\mathrm{Zn}$ ore extraction activities on uranium distribution in the Riou-Mort watershed (France), Sci. Tot. Envir., 382, 304-310, 2007.
Saari, H.-K., Schmidt, S., Castaing, P., Blanc, G., Sautour, B., Masson, O., and Cochran, J. K.: The particulate ${ }^{7} \mathrm{Be} /{ }^{210} \mathrm{~Pb}_{\mathrm{Xs}}$ and ${ }^{234} \mathrm{Th} /{ }^{210} \mathrm{~Pb}_{\mathrm{xs}}$ activity ratios as tracers for tidal-to-seasonal particle dynamics in the Gironde estuary (France): implications for the budget of particle-associated contaminants, Sci. Tot. Envir., 408, 4784-4794, 2010.

Savoye, N., David, V., Fontugne, M., Sautour, B., Etcheber, H., Jouanneau, J.-M., Billy, I., Middelburg, J.J.: Long-term variability of particulate organic matter characteristics in the Gironde estuary. ASLO Aquatic Sciences Meeting, 25-30 January, Nice, 2009.

Schafer, J., Blanc, G., Audry, S., Cossa, D., and Bossy, C.: Mercury in the Lot-Garonne River system (France): Sources, fluxes and anthropogenic component, Appl. Geochem., 21, 515-527, 2006.

Schmidt, S., Gonzalez, J.-L., Lecroart, P., Tronczyñski, J., Billy, I., and Jouanneau J.-M.: Bioturbation at the water-sediment interface of the Thau Lagoon: impact of shellfish farming, Aquatic Living Ressources, 20, 163-169, 2007.

Schmitt, F. G., Dur, G., Souissi, S., and Brizard Zongo, S.: Statistical properties of turbidity, oxygen and $\mathrm{pH}$ fluctuations in the Seine river estuary (France), Physica A, 387, 6613-6623, 2008.

Sottolichio, A. and Castaing, P.: A synthesis on seasonal dynamics of highly-concentrated structures in the Gironde estuary, Compte-rendus de l'Académie des Sciences de Paris, Science de la Terre et des Planètes 329, 795-800, 1999.

Stevenson, R. J. and Sabater, S.: Understanding effects of global change on river ecosystems: science to support policy in a changing world, Hydrobiol., 657, 3-18, 2010.

Uncles, R. J. and Stephens, J. A.: Turbidity and sediment transport in a muddy sub-estuary, Estuar. Coast. Shelf Res., 87, 213-224, 2010.

van Vliet, M. T. H. and Zwolsman, J. J. G.: Impact of summer droughts on the water quality of the Meuse river, J. Hydrol., 353, 1-17, 2008.

Woerther, P.: Coastal environment of the Seine Bay area monitoring by a new French system of automated measurement stations. Operational Oceanography: Implentation at the European and Regional Scales, edited by: Flemmings, N. C., Vallerga, S., Pinardi, N., Behrens H. W. A., Manzella, G., Prandle D., Stel, J. H., 2002.

Zolina, O., Simmer C., Gulev, S. K., and Kollet, S.: Changing structure of European precipitation: Longer wet periods leading to more abundant rainfalls, Geophys. Res. Lett., 37, L06704, doi:10.1029/2010GL042468, 2010. 